\title{
Laccase-Functionalized Graphene Oxide Assemblies as Efficient Nanobiocatalysts for Oxidation Reactions
}

\author{
Michaela Patila ${ }^{1}$, Antonios Kouloumpis ${ }^{2,3}$, Dimitrios Gournis ${ }^{2}$, Petra Rudolf ${ }^{3}$ and \\ Haralambos Stamatis ${ }^{1, *}$ \\ 1 Biotechnology Laboratory, Department of Biological Applications and Technologies, University of Ioannina, \\ Ioannina 45110, Greece; michaelapatila@gmail.com \\ 2 Department of Materials Science and Engineering, University of Ioannina, Ioannina 45110, Greece; \\ antoniokoul@gmail.com (A.K.); dgourni@uoi.gr (D.G.) \\ 3 Zernike Institute for Advanced Materials, University of Groningen, Nijenborgh 4, 9747 AG Groningen, \\ The Netherlands; p.rudolf@rug.nl \\ * Correspondence: hstamati@uoi.gr; Tel.: +30-26510-07116
}

Academic Editor: Gregory Schneider

Received: 31 December 2015; Accepted: 16 February 2016; Published: 25 February 2016

\begin{abstract}
Multi-layer graphene oxide-enzyme nanoassemblies were prepared through the multi-point covalent immobilization of laccase from Trametes versicolor (TvL) on functionalized graphene oxide (fGO). The catalytic properties of the fGO-TvL nanoassemblies were found to depend on the number of the graphene oxide-enzyme layers present in the nanostructure. The fGO-TvL nanoassemblies exhibit an enhanced thermal stability at $60{ }^{\circ} \mathrm{C}$, as demonstrated by a 4.7-fold higher activity as compared to the free enzyme. The multi-layer graphene oxide-enzyme nanoassemblies can efficiently catalyze the oxidation of anthracene, as well as the decolorization of an industrial dye, pinacyanol chloride. These materials retained almost completely their decolorization activity after five reaction cycles, proving their potential as efficient nano- biocatalysts for various applications.
\end{abstract}

Keywords: graphene oxide; laccase; nanoassemblies; immobilization; nanobiocatalysis

\section{Introduction}

Graphene, graphene oxide and their derivatives have attracted great interest in biotechnology and biomedicine applications such as in gene and drug delivery, bioimaging, as well as in the construction of biosensors and biomedical devices [1-3], since they combine outstanding characteristics such as very good mechanical and thermal stability, chemical inertness, and exceptional electronic properties. More specifically, in the field of nanobiotechnology the use of graphene oxide derivatives as immobilization supports for the development of effective nanobiocatalytic systems has been intensively investigated [4-7]. The large surface area, the abundant oxygen-containing surface functionalities, and the high water solubility of these nanomaterials create an ideal immobilization support for various bioactive molecules such as genes, drugs, antibodies and other proteins, including enzymes [8,9]. There have been extensive studies on the immobilization of enzymes onto graphene oxide and their use as biosensors [10,11] and nanobiocatalytic systems in various processes [12,13].

Regarding the development of effective nanobiocatalysts through grafting of enzymes onto nanomaterials, a new interesting approach is the immobilization of enzymes in multilayer systems through layer-by-layer deposition [14-16]. This method can be easily applied for the development of electrochemical biosensors since the immobilization of biomolecules is achieved under biocompatible conditions, and in addition to being simple and low cost, different recognition elements can be 
incorporated into the layers, to construct an active material for nanodevices detecting different compounds [14]. Such multilayer assemblies have recently been shown to increase the surface molecule loading and, thus leading to a higher performance of biosensors [17,18]. Layer-by-layer deposition has been also used for the development of a reliable and reproducible fabrication scheme for solid-supported purple membrane-based devices [19], as well as for photocatalytic hydrogen production performance [20]. Furthermore, the layer-by-layer method could be also applied to realize artificial multi-enzyme complexes for in vitro cascade reactions [21].

In the present study, we show that functionalized graphene oxide with terminal amine groups (fGO) can be used as building block for graphene oxide-enzyme nanoassemblies put together through sequential immobilization of an oxidase (laccase) onto the fGO sheets. To the best of our knowledge, this is the first report on the development of graphene oxide-enzyme nanoassemblies by the use of a simple protocol that allows the deposition of various fGO-enzyme layers until the desired thickness of the nanostructure is achieved. The application of these laccase nanoassemblies for the degradation of polycyclic aromatic hydrocarbons and the decolorization of dyes was investigated. Laccase ( $p$-diphenol:oxygen oxidoreductase E.C.1.10.3.2) is a multi-copper oxidase which catalyzes one-electron oxidation of phenolic molecules with the concomitant reduction of oxygen to water. Laccases are widely used for the development of biosensors [22-25] as well as in numerous biocatalytic applications of industrial interest [26-30]. These synthesized multi-layer graphene oxide-laccase nanoassemblies were found to have a very promising biocatalytic behavior (excellent oxidation activity, high operational stability, remarkable reusability). The protocol for synthesizing these novel graphene oxide-enzyme nanoassemblies should be extendable to other nanobiocatalytic assemblies with different enzyme functions and is therefore likely to have an important impact on the development of bioanalytical devices, biofuel cells and industrial biocatalysis.

\section{Materials and Methods}

\subsection{Materials}

Laccase from Trametes versicolor (13.6 U/mg, TvL), 2,2'-azino-bis(3-ethylbenzothiazoline-6sulphonic acid) (ABTS), anthracene, pinacyanol chloride (1,1'-diethyl-2,2'-carbocyanine chloride) and 1-hydroxybenzoitriazole (HBT) were purchased from Fluka (St. Louis, MO, USA) and used as received. All other solvents and reagents were of HPLC or analytical grade.

\subsection{Graphene Oxide Preparation and Functionalization}

Aqueous dispersions of graphene oxide were produced using a modified Staudenmaier's method from graphite powder (purum, $\leqslant 0.2 \mathrm{~mm}$; Fluka) [31]. Graphene oxide was further functionalized using hexamethylenediamine (Sigma-Aldrich, St. Louis, Mo, USA) for the addition of amino groups, as described in previous works [32,33].

\subsection{Immobilization of Laccase}

The multipoint covalent immobilization for the synthesis of multi-layer assemblies of nanomaterial and enzyme, was achieved using glutaraldehyde (Sigma-Aldrich) as cross-linking agent between the enzyme and the amino groups located on the surface of the nanomaterial (fGO), in a similar manner as described elsewhere [34]. Briefly, $3 \mathrm{mg}$ of fGO in $9.13 \mathrm{~mL}$ of acetate buffer $(0.1 \mathrm{M}, \mathrm{pH} 4.58)$ were sonicated for $30 \mathrm{~min}$ in the presence of $110 \mu \mathrm{L}$ Tween-20 (Sigma-Aldrich). After the dispersion of the nanomaterials, $1.76 \mathrm{~mL}$ of glutaraldehyde was added and the mixture was incubated under stirring for $1 \mathrm{~h}$ at $30^{\circ} \mathrm{C}$. The modified nanomaterials were separated by centrifugation at $6000 \mathrm{rpm}$ and washed three times with buffer solution to remove the excess of glutaraldehyde. The nanomaterials were re-dispersed in $5 \mathrm{~mL}$ buffer and then $1 \mathrm{~mL}$ laccase solution ( $3 \mathrm{mg}$ laccase) was added and the mixture was incubated under stirring for $1 \mathrm{~h}$ at $30^{\circ} \mathrm{C}$ (1st layer). $2 \mathrm{~mL}$ of fGO $(3 \mathrm{mg}$ nanomaterial), previously activated with glutaraldehyde, were added to the mixture and incubated 
under stirring for $1 \mathrm{~h}$ at $30^{\circ} \mathrm{C}$ (2nd layer). The above procedure was repeated till the desired number of fGO-TvL layers is achieved.

\subsection{Determination of Immobilization Yield}

The amount of immobilized enzyme was determined by calculating the protein concentration in the supernatant after the immobilization procedure using the bicinchoninic acid (BCA) assay [35]. Loading was estimated as the difference between the amount of the initial protein used and the amount of the protein in the supernatant after immobilization.

\subsection{Atomic Force Microscopy Studies}

AFM images were collected in tapping mode with a 3D Multimode Nanoscope, using Tap-300G silicon cantilevers (Ted Pella Inc., Redding, CA, USA) with a tip radius $<10 \mathrm{~nm}$ and a force constant of $\approx 20-75 \mathrm{~N} \cdot \mathrm{m}^{-1}$. Samples were deposited onto silicon wafers (P/Bor, single side polished) from aqueous solutions by drop casting.

\subsection{FT-IR Spectroscopy}

Infrared spectra covering the spectral range $400-4000 \mathrm{~cm}^{-1}$ were measured with a FT-IR 8400 infrared spectrometer (Shimadzu, Tokyo, Japan) equipped with a deuterated triglycine sulphate (DTGS) detector. Each spectrum was the average of 128 scans collected at $2 \mathrm{~cm}^{-1}$ resolution. Samples were in the form of $\mathrm{KBr}$ pellets containing ca. $2 \mathrm{wt} \%$ of the material.

\subsection{Raman Spectroscopy}

Raman spectra were recorded with a Micro-Raman system RM 1000 (RENISHAW, Old Town, UK) using a laser excitation line at $532 \mathrm{~nm}$ (laser diode). A $0.5-1 \mathrm{~mW}$ laser power was used with a $1 \mu \mathrm{m}$ focus spot in order to avoid photodecomposition of the sample.

\subsection{Determination of the Activity of Free TvL and of $f G O-T v L$ Nanoassemblies}

Standard laccase activity was determined by oxidation of ABTS at room temperature [36]. The reaction solution was composed of $1 \mathrm{mM}$ of ABTS in sodium acetate buffer (0.1 M, pH 4.58). Then a suitable amount of soluble enzyme or immobilized preparation (dispersed in acetate buffer) was added and the oxidation of ABTS was followed by measuring the absorbance change at $415 \mathrm{~nm}$ [36]. One unit was defined as the amount of the laccase that oxidized $1 \mu \mathrm{mol}$ of ABTS substrate per min. All experiments were performed in triplicate.

\subsection{Determination of the Stability of Free TvL and of $f G O-T v L$ Nanoassemblies}

Free or immobilized TvL ( $1 \mu \mathrm{g} / \mathrm{mL}$ and $50 \mu \mathrm{g} / \mathrm{mL}$, respectively) was incubated up to $24 \mathrm{~h}$ in acetate buffer $(0.1 \mathrm{M}, \mathrm{pH} 4.58)$ at $60^{\circ} \mathrm{C}$. Samples were withdrawn at predetermined time intervals to determine the remaining oxidation activity through the ABTS oxidation as described before. In the case of immobilized enzyme, the samples were first sonicated to achieve a well-dispersed mixture. All experiments were performed in triplicate.

\subsection{Anthracene Degradation by fGO-TvL Nanoassemblies}

All experiments were performed in $0.1 \mathrm{M}$ sodium acetate buffer $(\mathrm{pH} 4.58)$ containing $1 \%(v / v)$ Tween-20, $1 \mathrm{mM} \mathrm{HBT} \mathrm{(as} \mathrm{mediator),} \mathrm{a} \mathrm{final} \mathrm{concentration} \mathrm{of} 1 \mathrm{mg} / \mathrm{mL}$ immobilized laccase and $0.1 \mathrm{mM}$ concentration of anthracene in acetonitrile (Fluka). The mixtures were incubated in darkness at $30{ }^{\circ} \mathrm{C}$ under stirring at $800 \mathrm{rpm}$ for 3 days. Quantitative analysis of substrates and products was performed by HPLC, using a SUPELCOSIL ${ }^{\mathrm{TM}}$ LC-C18-DB column $(25 \mathrm{~cm} \times 4.6 \mathrm{~mm}, 5 \mu \mathrm{m})$ and a diode array UV detector (Shimadzu). Linear gradient from $75 \%$ to $100 \%$ methanol (Fluka) in water (containing $0.1 \%$ acetic acid) was employed for $20 \mathrm{~min}$. The elution was performed at $30{ }^{\circ} \mathrm{C}$ at a flow rate of 
$1 \mathrm{~mL} / \mathrm{min}$. The determination of the conversion yield was based on the decrease of the concentration of anthracene. Identification of the product (9,10-anthraquinone) was confirmed by comparison of its retention time and UV-Vis spectrum with that of the original compound.

\subsection{Dye decolorization}

The decolorization activity of fGO-TvL nanoassemblies was measured by following the color elimination of pinacyanol chloride in acetate buffer $(0.1 \mathrm{M}, \mathrm{pH} 4.58)$. The reaction mixture contained $100 \mu \mathrm{g} / \mathrm{mL}$ pinacyanol chloride and $500 \mu \mathrm{g} / \mathrm{mL}$ of fGO-TvL; it was incubated at $30^{\circ} \mathrm{C}$ under stirring at $800 \mathrm{rpm}$. At predetermined time intervals $20 \mu \mathrm{L}$ aliquots were removed from the reaction mixture and added to a 1:1 $(v / v)$ mixture of methanol and sodium acetate buffer $(0.1 \mathrm{M}, \mathrm{pH} 4.58)$. The remaining concentration of the dye was monitored by measuring the absorbance at $603 \mathrm{~nm}$ using an extinction coefficient for pinacyanol chloride equal to $\varepsilon=82,350 \mathrm{M}^{-1} \cdot \mathrm{cm}^{-1}$ [37].

\subsection{Reuse of fGO-TvL Nanoassemblies}

The enzymatic decolorization of pinacyanol chloride was also chosen as test case in order to investigate the reusability of fGO-TvL nanoassemblies. The reaction mixture $(0.5 \mathrm{~mL})$ contained $100 \mu \mathrm{g} / \mathrm{mL}$ pinacyanol chloride in sodium acetate buffer $(0.1 \mathrm{M}, \mathrm{pH} 4.58)$ and $500 \mu \mathrm{g} / \mathrm{mL}$ of fGO-TvL; it was incubated at $30{ }^{\circ} \mathrm{C}$ under stirring at $800 \mathrm{rpm}$ for $5 \mathrm{~h}$. After each reaction cycle, the fGO-TvL was separated by centrifugation at 12,000 rpm and washed three times with acetate buffer $(0.1 \mathrm{M}, \mathrm{pH} 4.58)$. The fGO-TvL nanoassemblies were repeatedly used five times. The following equation was employed to estimate the decolorization yield after each reaction cycle:

$$
\text { Decolorization }(\%)=\left(C_{i}-C_{t}\right) / C_{i} * 100
$$

where $C_{i}$ is the initial concentration and $C_{t}$ is the concentration after incubation time.

\section{Results and Discussion}

In the present work nanobiocatalytic assemblies of fGO and laccase form Trametes versicolor (TvL) were obtained through multi-point covalent immobilization of enzyme on the surface of functionalized graphene oxide with terminal free amino-groups, using glutaraldehyde as cross-linker (Scheme 1). After grafting TvL onto the first fGO layer, the assembly was again exposed to fGO, which readily linked to the enzyme and this sequence was continued until the desired number of fGO-TvL layers was produced. As reported here below, the morphology of the nanoassemblies was probed by atomic force microscopy, their activity and thermal stability determined and their biocatalytic properties investigated using the oxidation of a polycyclic hydrocarbon (anthracene) and of an industrial dye (pinacyanol chloride) as model reactions. A reusability test concluded the study.

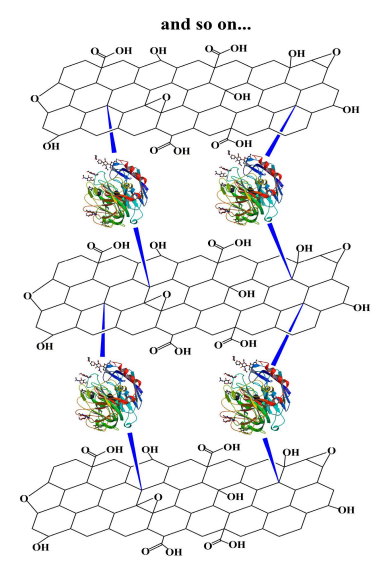

Scheme 1. Development of graphene oxide-enzyme nanoassemblies. 


\section{1. $A F M$}

Typical AFM images of the fGO-TvL (1st layer) deposited on a Si-wafer are shown in Figure 1. The protrusions visible on top of the fGO sheet suggest that TvL has been successfully immobilized. The analysis of the topographical height profile (Figure 1b) gives an average thickness of the fGO flake of about $1 \mathrm{~nm}$ and of TvL of $\approx 11 \mathrm{~nm}$.

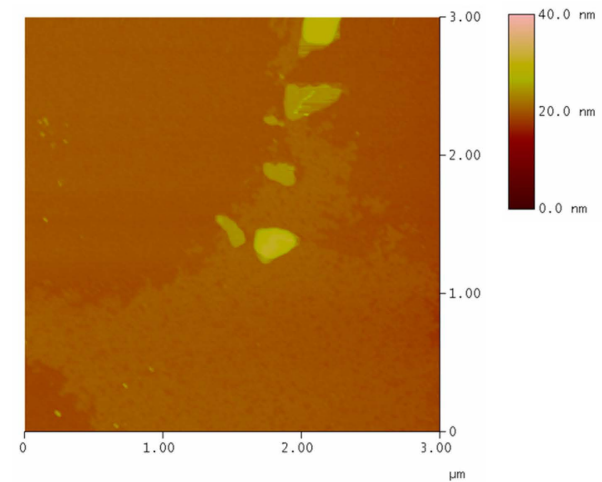

(a)
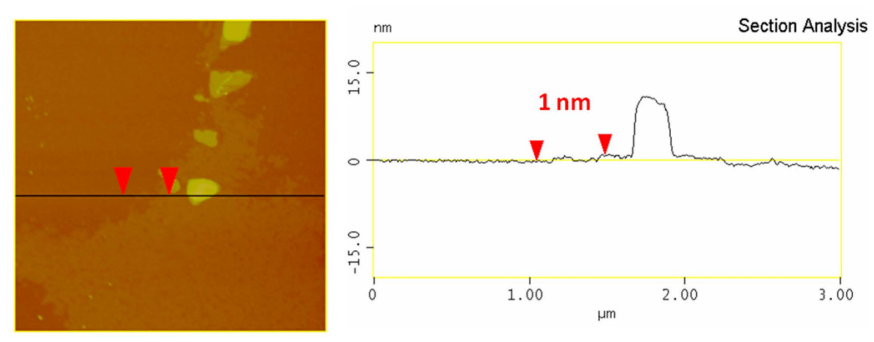

(b)

Figure 1. (a) AFM height images and (b) section analysis profile of a single fGO-TvL layer.

AFM images of a fGO-TvL multilayer (fGO-TvL-fGO-TvL-fGO-TvL-fGO) are shown in Figure 2. The multi-layer structure consisting of $4 \mathrm{fGO}$ layers is visible both in height (Figure 2a) as well as in phase (Figure $2 b$ ) images. This structure was further confirmed by the topographical height profile (Figure 2c). Comparing the the overall thickness of the fGO-TvL monolayer (Figure 1b), $12 \mathrm{~nm}$, with the average thickness of multilayer of circa $37 \mathrm{~nm}$ deduced from (Figure 2c) one concludes that the multilayer structure consists of 3 layers of fGO-TvL $(3 \times 12=36 \mathrm{~nm})$ plus one functionalized graphene oxide sheet $(1 \mathrm{~nm})$.

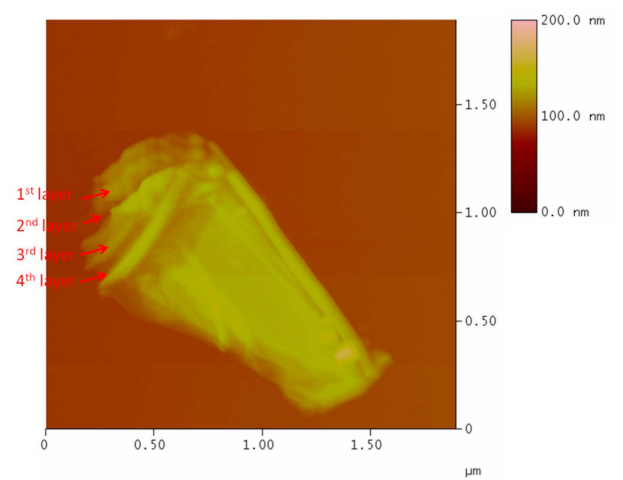

(a)

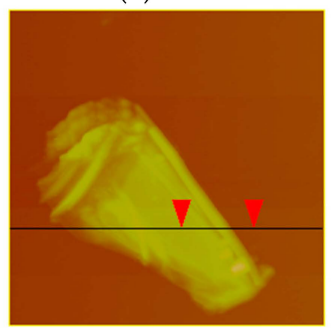

(c)

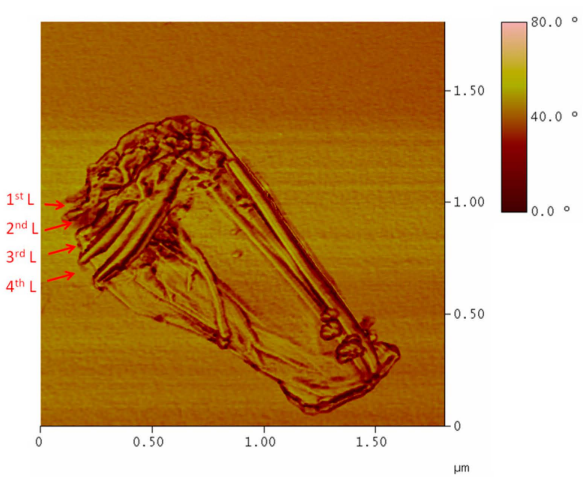

(b)

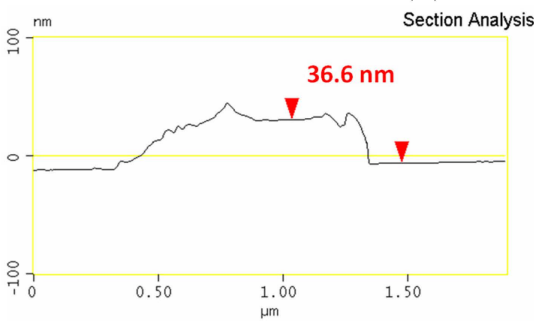

Figure 2. (a) AFM height image (b) phase image and (c) and section analysis profile of a fGO-TvL multilayer. 


\subsection{Spectroscopic Characterization of $f G O-T v L$ Nanoassemblies}

The FT-IR spectra of the functionalized GO-NH${ }_{2}$ and fGO-TvL multilayer nanoassemblies (fGO-TvL-fGO-TvL-fGO-TvL and fGO-TvL-fGO-TvL-fGO-TvL-fGO) were compared with those of pristine GO and TvL as shown in Figure 3. The spectra display all the characteristic bands of GO and TvL. More specifically, GO exhibits a weak band at $1620 \mathrm{~cm}^{-1}$ assigned to the $\mathrm{C}=\mathrm{O}$ stretching vibrations of the $\mathrm{COOH}$ groups, a strong band at $1396 \mathrm{~cm}^{-1}$ assigned to the $\mathrm{O}-\mathrm{H}$ deformations of the $\mathrm{C}-\mathrm{OH}$ groups, a strong band at $1062 \mathrm{~cm}^{-1}$ attributed to $\mathrm{C}-\mathrm{O}$ stretching vibrations, and a weak band at $1230 \mathrm{~cm}^{-1}$ assigned to asymmetric stretching of $\mathrm{C}-\mathrm{O}-\mathrm{C}$ bridges in epoxy groups and/or to deformation vibrations of $\mathrm{O}-\mathrm{H}$ in the carboxylic acid groups [31]. The same bands are also present in the case of the functionalized GO and fGO-TvL multilayer nanoassemblies, while the intensity of the band at $1230 \mathrm{~cm}^{-1}$ decreases due to the nucleophilic substitution reactions between the amine end groups of the organic molecules and the epoxy groups of the GO [38,39], confirming the successful functionalization and immobilization of GO and enzyme, respectively. Finally, two extra bands at 2927 and $2856 \mathrm{~cm}^{-1}$, due to asymmetric and symmetric stretching vibrations of $\mathrm{CH}_{2}$ groups, confirm the presence of the amine derivatives in the fGO-TvL multilayer nanoassemblies.

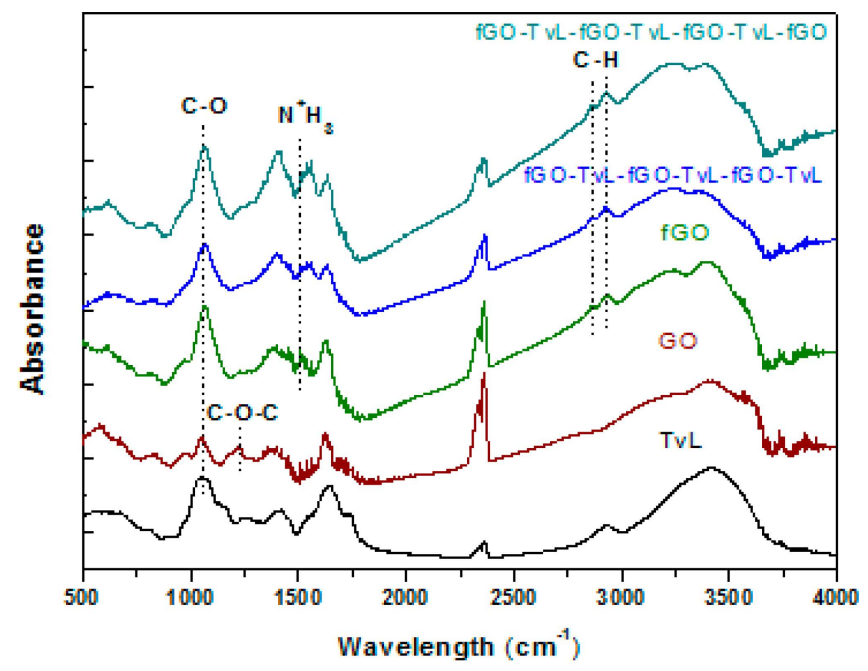

Figure 3. FT-IR spectra of the functionalized GO and fGO-TvL multilayer nanoassemblies compared to those of pristine GO and TvL.

Raman spectra of the functionalized GO and fGO-TvL multilayer nanoassemblies (fGO-TvL-fGO-TvL-fGO-TvL and fGO-TvL-fGO-TvL-fGO-TvL-fGO) compared with the pristine GO and TvL are shown in Figure 4. All spectra are similar and typical of graphene oxide-based materials without significant differences. In particular, the spectra show the characteristic $G$ peak at $1580 \mathrm{~cm}^{-1}$, which is due to the first-order scattering of $E_{2 g}$ mode, and the D band at $1349 \mathrm{~cm}^{-1}$, which stems from disorder in the $s p^{2}$-hybridized carbon atoms and is characteristic of lattice distortions in the graphene sheets due to the extensive oxidation [40]. The $\mathrm{D}$ peak intensity is not related to the number of graphene layers but only to the amount of disorder. Thus, the shape and intensity ratio of $D$ to $G\left[I_{D} / I_{G}\right]$ bands can be used to evaluate the quality of graphene-based materials [41]. The $\mathrm{I}_{\mathrm{D}} / \mathrm{I}_{\mathrm{G}}$ intensity ratio was found to be 1.03 in the case of GO, while the ratios for both fGO-TvL multilayers nanoassemblies is equal to 1.07 indicating that the immobilization of the enzyme on the graphene nanosheets leaves the structure of GO unaffected. 


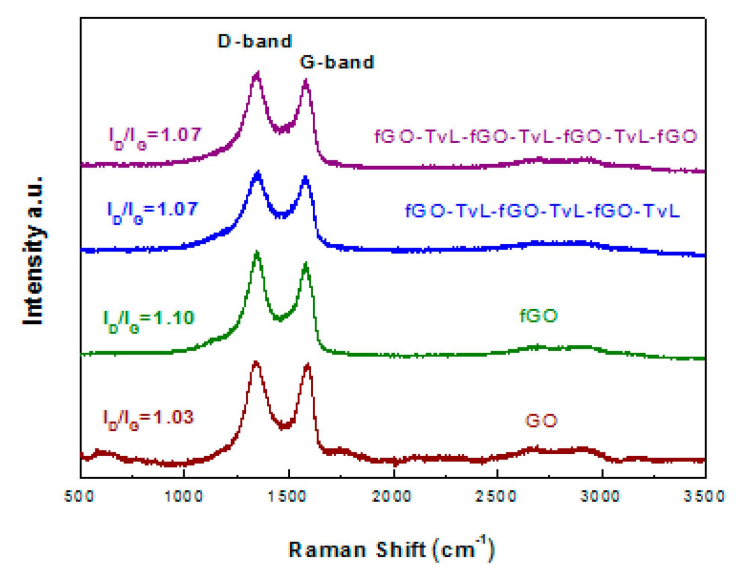

Figure 4. Raman spectra of the functionalized GO and fGO-TvL multilayer nanoassemblies compared to that of pristine GO.

\subsection{Oxidation Activity of $f G O-T v L$ Nanoassemblies}

The catalytic activity of the fGO-TvL nanoassemblies was determined using the oxidation of ABTS at room temperature as model reaction. The catalytic activity of TvL was decreased from $13.6 \mathrm{U} / \mathrm{mg}$ of free enzyme to $0.55 \mathrm{U} / \mathrm{mg}$ for fGO-TvL. The reduction of the enzyme activity upon immobilization observed here is in accordance with that reported for several enzymes and could be due either to partial denaturation of enzymes during the immobilization procedure or to mass transfer effects which can lead to a reduced catalytic efficiency compared to soluble enzymes [42,43].

As it can be seen from Table 1, the catalytic activity of fGO-TvL nanoassemblies is increased as the number of $\mathrm{fGO}$ and enzyme layers increases. The increase of activity with the addition of a second layer of fGO is possibly due to interactions between the enzyme and the fGO sheet during the immobilization procedure that lead to a more active conformation of the enzyme. Adding a freely accesible enzyme on top of the nanoassembly, as in the case of fGO-TvL-fGO-TvL and fGO-TvL-fGO-TvL-fGO-TvL, increases the catalytic activity, which could stem from the fact that the external enzyme layer is easily accessible to substrate molecules. When instead an external layer of fGO was added on top of the enzyme, as in the case of fGO-TvL-fGO-TvL-fGO and fGO-TvL-fGO-TvL-fGO-TvL-fGO), the activity of the nanobiocatalysts decreased. This seems to indicate that as the nanoassembly gets thicker, the benefit of the extra fGO layer in inducing a more active enzyme conformation is outweighed by a reduced substrate availability when the enzyme is located in an internal layer of the nanoassembly. It is worthy to note that the addition of more than $3 \mathrm{fGO}$ layers reduces the dispersion of the material in the reaction medium, which in turn could lead to a decrease of the catalytic activity as observed for fGO-TvL-fGO-TvL-fGO-Tv-fGO.

Table 1. Activity of fGO-TvL nanoassemblies through ABTS oxidation.

\begin{tabular}{cc}
\hline Immobilized TvL & Activity (U/mg of Immobilized Enzyme) \\
\hline fGO-TvL & $0.55 \pm 0.07$ \\
fGO-TvL-fGO & $1.00 \pm 0.13$ \\
fGO-TvL-fGO-TvL & $1.63 \pm 0.15$ \\
fGO-TvL-fGO-TvL-fGO & $0.97 \pm 0.10$ \\
fGO-TvL-fGO-TvL-fGO-TvL & $4.89 \pm 0.63$ \\
fGO-TvL-fGO-TvL-fGO-Tv-fGO & $1.05 \pm 0.17$ \\
\hline
\end{tabular}

\subsection{Stability of fGO-TvL Nanoassemblies}

The thermal and operational stability of immobilized enzymes grafted onto various nanosupports is of great importance for technological applications of nanobiocatalytic systems, including biosensing 
and nanobiocatalysis $[44,45]$. In the present work, the thermal stability of the prepared fGO-TvL nanoassemblies was investigated. The remaining laccase activity of fGO-TvL nanoassemblies, was determined after incubation for up to $24 \mathrm{~h}$ in acetate buffer $(0.1 \mathrm{M}, \mathrm{pH} 4.58)$ at $60{ }^{\circ} \mathrm{C}$, and compared to that of the free enzyme.

Figure 5 shows the thermal stability of free and immobilized TvL, while the half-life constants of the fGO-TvL nanoassemblies are presented in Table 2. As it can be seen, all fGO-TvL nanoassemblies exhibited significant higher stability compared to the free enzyme. The free enzyme loses $90 \%$ of its initial activity after $4 \mathrm{~h}$ incubation at $60{ }^{\circ} \mathrm{C}$ and is almost fully deactivated after $24 \mathrm{~h}$ incubation. On the other hand, the multi-layer fGO-TvL nanoassemblies maintain up to $40 \%$ of their initial activity after $24 \mathrm{~h}$ of incubation, indicating that the immobilization of TvL onto fGO results in more stable biocatalysts compared to the native soluble enzymes, in line with literature reports on the immobilization of other enzymes on carbon-based nanomaterials [26,46-48]. The observed improvement in the stability of TvL may be due to the combined action of a reduced molecular mobility and an improved conformational stabilization of the enzyme resulting from the multi-point attachment of TvL to the fGO layers. In other words, the large surface area of the fGO sheets, as well as the formation of stable covalent bonds between the fGO and TvL seem to protect the conformational state of TvL, resulting in stabilization of the protein molecules against thermal denaturation. The beneficial effect of the fGO sheets for TvL stabilization increases as the number of fGO-TvL layers grows, indicating that enzyme-graphene oxide nanoassemblies can be successfully used as effective supports where enzymes are protected from thermal inactivation.

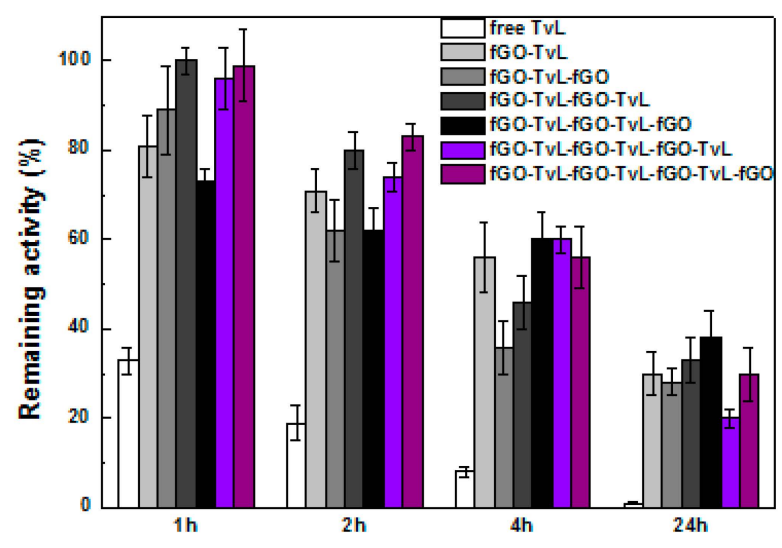

Figure 5. Residual catalytic activity of free TvL and of fGO-TvL assemblies after various incubation times in acetate buffer at $60{ }^{\circ} \mathrm{C} .100 \%$ indicates the activity of laccase at $t=0 \mathrm{~min}$.

Table 2. Half-life constants of fGO-TvL nanoassemblies.

\begin{tabular}{cc}
\hline Enzyme & $\boldsymbol{t}_{\mathbf{1 / 2}}$ (h) \\
\hline Free TvL & $0.9 \pm 0.1$ \\
fGO-TvL & $3.7 \pm 0.4$ \\
fGO-TvL-fGO & $2.9 \pm 0.2$ \\
fGO-TvL-fGO-TvL & $2.3 \pm 0.1$ \\
fGO-TvL-fGO-TvL-fGO & $4.1 \pm 0.5$ \\
fGO-TvL-fGO-TvL-fGO-TvL & $4.3 \pm 0.4$ \\
fGO-TvL-fGO-TvL-fGO-TvL-fGO & $4.1 \pm 0.5$ \\
\hline
\end{tabular}

\subsection{Use of fGO-TvL Nanoassemblies for the Oxidation of Anthracene}

Polycyclic aromatic hydrocarbons (PAHs) are highly toxic industrial pollutants, resulting from processes such as coal gasification, coking, and wood preservation. Due to their toxic effects PAHs 
pose a serious health risk to all forms of life, including humans, and some PAHs are known to be highly mutagenic and carcinogenic, thus their degradation is of high importance [49].

In order to evaluate the ability of fGO-TvL nanoassemblies to catalyze the oxidation of PAHs, anthracene was used as model substrate and its biodegradation by fGO-TvL nanoassemblies in the presence of the mediator HBT $(1 \mathrm{mM})$ was studied. The mediator HBT acts as a sort of electron shuttle between the enzyme and the substrate. Once oxidized by laccase, the mediator diffuses away from the enzymatic pocket and in turn oxidizes other molecules, extending the range of substrates susceptible to the enzymatic action and increasing the catalytic activity of the enzyme [50,51].

The degradation of anthracene by different fGO-TvL nanoassemblies is presented in Table 3; each percentage is the average of two measurements. In all cases studied, the nanoassemblies efficiently catalyze the biodegradation of anthracene, and in many cases, the conversion yield is higher compared to that of free laccase. The main intermediate oxidation product was identified as 9,10-anthraquinone, in accordance with other studies [52,53]. It is interesting to note that the degradation yield of fGO-TvL assemblies increases with the addition of fGO and enzyme layers. The degradation of anthracene by fGO-TvL (one layer) was $37.2 \%$ after 3 days of incubation at $30{ }^{\circ} \mathrm{C}$, while the degradation efficiency of multi-layer fGO-TvL nanoassemblies under the same conditions reaches values up to $98 \%$. These results can probably be linked to the increased stability of thicker nanoassemblies, as described above, indicating that multi-layer fGO-TvL nanoassemblies promise to be successful in applications for the detection and degradation of polyaromatic pollutants.

Table 3. Degradation of anthracene by fGO-TvL nanoassemblies.

\begin{tabular}{cc}
\hline Enzyme & Anthracene Degradation (\%) \\
\hline Free TvL & 96.5 \\
fGO-TvL & 37.2 \\
fGO-TvL-fGO & 89.3 \\
fGO-TvL-fGO-TvL & 98.6 \\
fGO-TvL-fGO-TvL-fGO & 93.8 \\
fGO-TvL-fGO-TvL-fGO-TvL & 97.4 \\
fGO-TvL-fGO-TvL-fGO-TvL-fGO & 97.8 \\
\hline
\end{tabular}

\subsection{Use of fGO-TvL Nanoassemblies for Dye Decolorization}

Synthetic dyes originate mainly from textile and plastic industries and are resistant to biodegradation, resulting in serious health hazards to animals and humans. Laccases have been found to be able to catalyze the oxidation of dyes and have potential applications in detection [54] and bioremediation of dye-containing industrial effluents [55].

To investigate the ability of fGO-TvL to catalyze the degradation of dyes, we chose as model substrate pinacyanol chloride, a symmetric trimethinecyanine dye widely applied as an optical sensitizer in photographic processes [56]. Figure 6 shows the efficiency of various fGO-TvL nanoassemblies in inducing pinacyanol chloride decolorization. In all cases studied, the immobilized laccase was found to be able to decolorize the dye. The initial reaction rate for the decolorization of pinacyanol chloride catalyzed by free TvL was up to 20-fold higher than that observed for all nanoassemblies tested. However, we would like to note that the low operational stability observed for free TvL (Table 2), as well as the fact that the free enzyme cannot be reused, make the application of free enzyme for such a process inefficient in an industrial setting. As seen in Table 4, the reaction rate for the decoloriztion of pinacyanol chloride catalyzed by multilayered nanoassemblies such as fGO-TvL-fGO-TvL-fGO-TvL is up to 2.2 times higher compared to that observed for a single layer of immobilized laccase (fGO-TvL). The reaction rate of these multilayered nanoassemblies slightly decreases when an external layer of fGO was added (as in the case of fGO-TvL-fGO-TvL-fGO and fGO-TvL-fGO-TvL-fGO-TvL-fGO), which is probably correlated to reduced substrate availability as discussed above for the oxidation of ABTS by fGO-TvL nanoassemblies. 


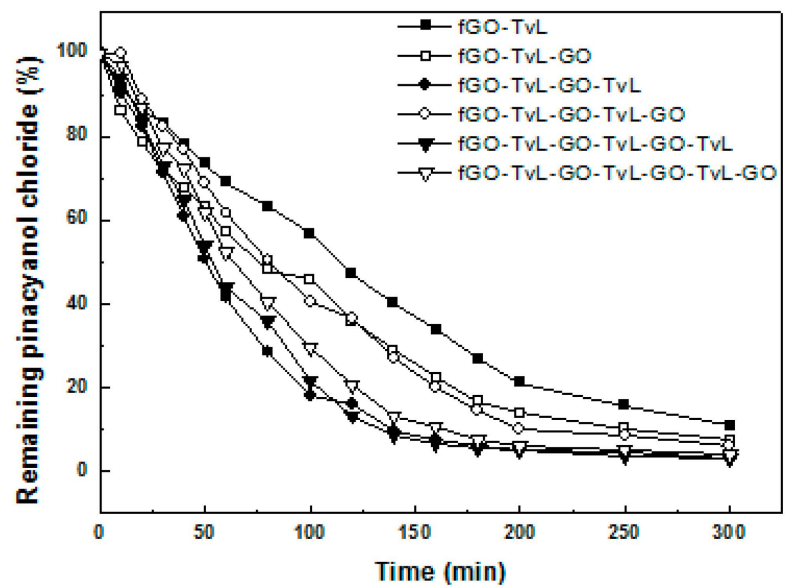

Figure 6. Laccase-catalyzed decolorization of pinacyanol chloride in acetate buffer $0.1 \mathrm{M}, \mathrm{pH} 4.58$.

Table 4. Reaction rates of fGO-TvL nanoassemblies for the decolorization of pinacyanol chloride.

\begin{tabular}{cc}
\hline Immobilized TvL & Reaction Rate $\left(\boldsymbol{\mu M} \cdot \mathbf{m i n}^{-\mathbf{1}} \cdot \boldsymbol{\mu g}^{-\mathbf{1}}\right.$ Enzyme $)$ \\
\hline fGO-TvL & $0.20 \pm 0.03$ \\
fGO-TvL-fGO & $0.36 \pm 0.05$ \\
fGO-TvL-fGO-TvL & $0.45 \pm 0.07$ \\
fGO-TvL-fGO-TvL-fGO & $0.38 \pm 0.06$ \\
fGO-TvL-fGO-TvL-fGO-TvL & $0.46 \pm 0.08$ \\
fGO-TvL-fGO-TvL-fGO-TvL-fGO & $0.43 \pm 0.08$ \\
\hline
\end{tabular}

\subsection{Reusability of the Nano-Ezyme Assemblies}

If fGO-TvL nanoassemblies are to be employed for sustainable industrial applications, waste minimisation by reuse is an important issue. Reuse was therefore investigated with the oxidation of pinacyanol chloride as model reaction. As it can be seen from Figure 7, when five reaction cycles ( $25 \mathrm{~h}$ of total operation) were completed, the ability of graphene oxide-enzyme nanoassemblies to catalyzed the decolorization of dye was highly maintained (up to $94 \%$ ), especially when multi-layer fGO-TvL nanoassemblies were used as biocatalyst. This indicates that the addition of extra fGO-TvL layers to the nanoassembly not only benefits the thermal stability and reaction efficiency, but also results in reusable nanobiocatalysts.

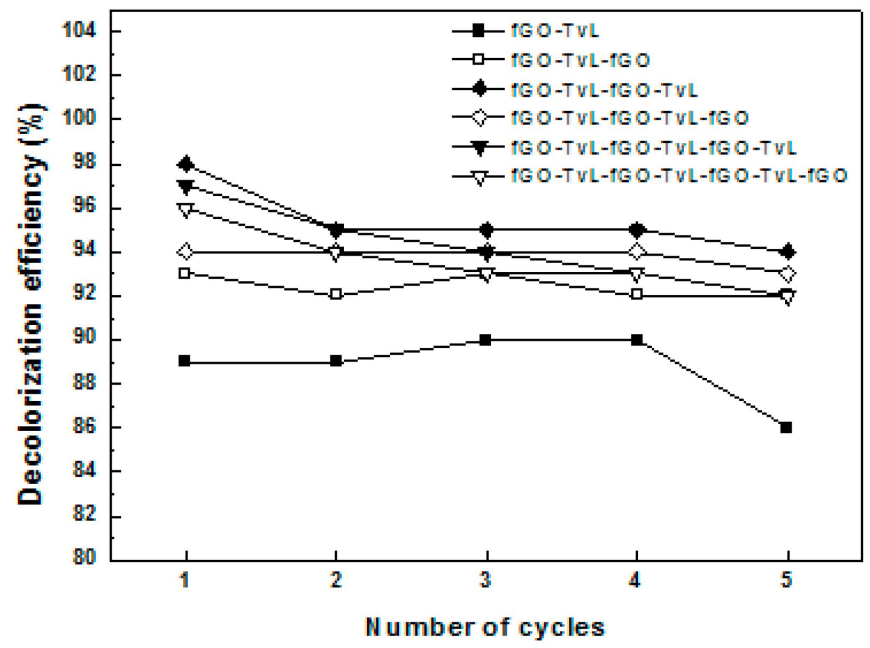

Figure 7. Reusability of fGO-TvL nanoassemblies in the batch oxidation of pinacyanol chloride. 


\section{Conclusions}

In the present study, we demonstrated the development of novel graphene oxide-enzyme assemblies through the multi-point covalent immobilization of laccase from Trametes versicolor on functionalized graphene oxide and their use in different biocatalytic applications. The catalytic activity of the fGO-TvL nanoassemblies, as well as their ability to catalyze the degradation of anthracene and pinacyanol chloride, increased with the number of nanomaterial and enzyme layers and was higher when the external layer of the multi-layer nanoassemblies was formed by the enzyme. Moreover, the graphene oxide-enzyme nanoassemblies exhibited higher thermal stability than the free enzyme and reactivity was maintained at higher temperatures when the number of fGO-TvL layers increased. The high catalytic activity against various substrates together with the enhanced thermal and operational stability, make these structures promising nanobiocatalytic systems for use in bioanalytical devices, biofuel cells and biotransformations.

Acknowledgments: This research project was supported from the Bilateral Cooperation Program IKYDA 2015 between the Greek State Scholarships Foundation, IKY, Athens, Greece and the German Academic Exchange Service, DAAD, Bonn, Germany.

Author Contributions: D.G., P.R. and H.S. conceived and designed the experiments; M.P. and A.K. performed the experiments and analyzed the data; M.P. and H.S. wrote the paper.

Conflicts of Interest: The authors declare no conflict of interest.

\section{Abbreviations}

The following abbreviations are used in this manuscript:

$\begin{array}{ll}\text { ABTS } & \text { 2,2'-azino-bis(3-ethylbenzothiazoline-6-sulphonic acid } \\ \text { AFM } & \text { Atomic Force Microscopy } \\ \text { fGO } & \text { Functionalized graphene oxide with terminal amine groups } \\ \text { HBT } & \text { 1-hydroxybenzoitriazole } \\ \text { HPLC } & \text { High-Performance Liquid Chromatography } \\ \text { PAHs } & \text { Polycyclic aromatic hydrocarbons } \\ \text { TvL } & \text { Laccase from Trametes versicolor } \\ \text { UV-Vis } & \text { Ultra-violet-Visible }\end{array}$

\section{References}

1. Goenka, S.; Sant, V.; Sant, S. Graphene-based nanomaterials for drug delivery and tissue engineering. J. Control. Release 2014, 173, 75-88. [CrossRef] [PubMed]

2. Krishna, K.V.; Ménard-Moyon, C.; Verma, S.; Bianco, A. Graphene-based nanomaterials for nanobiotechnology and biomedical applications. Nanomedicine 2013, 8, 1669-1688. [CrossRef] [PubMed]

3. Du, D.; Yang, Y.; Lin, Y. Graphene-based materials for biosensing and bioimaging. MRS Bull. 2012, 37, 1290-1296. [CrossRef]

4. Pavlidis, I.V.; Patila, M.; Bornscheuer, U.T.; Gournis, D.; Stamatis, H. Graphene-based nanobiocatalytic systems: Recent advances and future prospects. Trends Biotechnol. 2014, 32, 312-320. [CrossRef] [PubMed]

5. Jin, L.; Yang, K.; Yao, K.; Zhang, S.; Tao, H.; Lee, S.T.; Liu, Z.; Peng, R. Functionalized graphene oxide in enzyme engineering: A selective modulator for enzyme activity and thermostability. ACS Nano 2012, 6, 4864-4875. [CrossRef] [PubMed]

6. Li, Q.; Fan, F.; Wang, Y.; Feng, W.; Ji, W. Enzyme immobilization on carboxyl-functionalized graphene oxide for catalysis in organic solvent. Ind. Eng. Chem. Res. 2013, 52, 6343-6348. [CrossRef]

7. Cipolatti, E.P.; Silva, M.J.A.; Klein, M.; Feddern, V.; Feltes, M.M.C.; Oliveira, J.V.; Ninow, J.L.; Oliveira, D. Current status and trends in enzymatic nanoimmobilization. J. Mol. Catal. B Enzym. 2014, 99, 56-67. [CrossRef]

8. Gokhale, A.A.; Lu, J.; Lee, I. Immobilization of cellulase on magnetoresponsive graphene nano-supports. J. Mol. Catal. B Enzym. 2013, 90, 76-86. [CrossRef] 
9. Liu, J.; Cui, L.; Losic, D. Graphene and graphene oxide as new nanocarriers for drug delivery applications. Acta Biomater. 2013, 9, 9243-9257. [CrossRef] [PubMed]

10. Fang, Y.; Wang, E. Electrochemical biosensors on platforms of graphene. Chem. Commun. 2013, 49, 9526-9539. [CrossRef] [PubMed]

11. Zhang, X.; Liao, Q.; Chu, M.; Liu, S.; Zhang, Y. Structure effect on graphene-modified enzyme electrode glucose sensors. Biosens. Bioelectron. 2014, 52, 281-287. [CrossRef] [PubMed]

12. Lau, S.C.; Lim, H.N.; Basri, M.; Masoumi, H.R.F.; Tajudin, A.A.; Huang, N.M.; Pandikumar, A.; Chia, C.H.; Andou, Y. Enhanced biocatalytic esterification with lipase-immobilized chitosan/graphene oxide beads. PLOS ONE 2014, 9, e104695.

13. Patel, V.; Gajera, H.; Gupta, A.; Manocha, L.; Madamwar, D. Synthesis of ethyl caprylate in organic media using Candida rugosa lipase immobilized on exfoliated graphene oxide: Process parameters and reusability studies. Biochem. Eng. J. 2015, 95, 62-70. [CrossRef]

14. Dronov, R.; Kurth, D.G.; Möhwald, H.; Scheller, F.W.; Lisdat, F. A self-assembled cytochrome c/xanthine oxidase multilayer arrangement on gold. Electrochim. Acta 2007, 53, 1107-1113. [CrossRef]

15. Riklin, A.; Willner, I. Glucose and acetylcholine sensing multilayer enzyme electrodes of controlled enzyme layer thickness. Anal. Chem. 1995, 67, 4118-4126. [CrossRef]

16. Lisdat, F.; Dronov, R.; Möhwald, H.; Scheller, F.W.; Kurth, D. Self-assembly of electro-active protein architectures on electrodes for the construction of biomimetic signal chains. Chem. Commun. 2009, 3, 277-283. [CrossRef]

17. Feifel, S.C.; Lisdat, F. Silica nanoparticles for the layer-by-layer assembly of fully electro-active cytochrome c multilayers. J. Nanobiotechnol. 2011, 9, 59-71. [CrossRef] [PubMed]

18. Sun, Y.; Yan, F.; Yang, W.; Sun, C. Multilayered construction of glucose oxidase and silica nanoparticles on $\mathrm{Au}$ electrodes based on layer-by-layer covalent attachment. Biomaterials 2006, 27, 4042-4049. [CrossRef] [PubMed]

19. Chen, H.M.; Lin, C.J.; Jheng, K.R.; Kosasih, A.; Chang, J.Y. Effect of graphene oxide on affinity-immobilization of purple membranes on solid supports. Colloids Surf. B 2014, 116, 482-488. [CrossRef] [PubMed]

20. Wang, P.; Dimitrijevic, N.M.; Chang, A.Y.; Schaller, R.D.; Liu, Y.; Rajh, T.; Rozhkova, E.A. Photoinduced electron transfer pathways in hydrogen-evolving reduced graphene oxide-boosted hybrid nano-bio catalyst. ACS Nano 2014, 8, 7995-8002. [CrossRef] [PubMed]

21. Lu, J.; Cui, D.; Li, H.; Zhang, Y.; Liu, S. Cytochrome P450 bienzymes assembled on Au/chitosan/reduced graphene oxide nanosheets for electrochemically-driven drug cascade metabolism. Electrochim. Acta 2015, 165, 36-44. [CrossRef]

22. Mei, L.P.; Feng, J.J.; Wu, L.; Zhou, J.Y.; Chen, J.R.; Wang, A.J. Novel phenol biosensor based on laccase immobilized on reduced graphene oxide supported palladium-copper alloyed nanocages. Biosens. Bioelectron. 2015, 74, 347-352. [CrossRef] [PubMed]

23. Aguila, S.A.; Shimomoto, D.; Ipinza, F.; Bedolla-Valdez, Z.I.; Romo-Herrera, J.; Contreras, O.E.; Farías, M.H.; Alonso-Núñez, G. A biosensor based on Coriolopsis gallica laccase immobilized on nitrogen-doped multiwalled carbon nanotubes and graphene oxide for polyphenol detection. Sci. Technol. Adv. Mater. 2015, 16. [CrossRef]

24. Ormategui, N.; Veloso, A.; Leal, G.P.; Rodriguez-Couto, S.; Tomovska, R. Design of stable and powerful nanobiocatalysts, based on enzyme laccase immobilized on self-assembled 3D graphene/polymer composite hydrogels. ACS Appl. Mater. Interfaces 2015, 7, 14104-14112. [CrossRef] [PubMed]

25. Rodríguez-Delgado, M.M.; Alemán-Nava, G.S.; Rodríguez-Delgado, J.M.; Dieck-Assad, G.; Martínez-Chapa, S.O.; Barceló, D.; Parra, R. Laccase-based biosensors for detection of phenolic compounds. Trends Anal. Chem. 2015, 74, 21-45. [CrossRef]

26. Camarero, S.; García, O.; Vidal, T.; Colom, J.; del Río, J.C.; Gutiérrez, A.; Martínez, M.J.; Martínez, A.T. Flax pulp bleaching and residual lignin modification by laccase-mediator systems. Prog. Biotechnol. 2002, 21, 213-222.

27. Chandra, R.P.; Lehtonen, L.K.; Ragauskas, A.J. Modification of high lignin content kraft pulps with laccase to improve paper strength properties. Laccase treatment in the presence of gallic acid. Biotechnol. Prog. 2004, 20, 255-261. [CrossRef] [PubMed]

28. Nyanhongo, G.S.; Gübitz, G.; Sukyai, P.; Leitner, C.; Haltrich, D.; Ludwig, R. Oxidoreductases from Trametes spp. in biotechnology: A wealth of catalytic activity. Food Technol. Biotechnol. 2007, 45, 250-268. 
29. Fernandez-Fernandez, M.; Sanroman, M.A.; Moldes, D. Recent developments and applications of immobilized laccase. Biotechnol. Adv. 2012, 31, 1808-1825. [CrossRef] [PubMed]

30. Tzialla, A.A.; Taha, A.A.; Kalogeris, E.; Stamatis, H. Improving the catalytic performance of fungal laccases in monoterpene-based reaction systems. Biotechnol. Lett. 2009, 31, 1451-1456. [CrossRef] [PubMed]

31. Enotiadis, A.; Angeli, K.; Baldino, N.; Nicotera, I.; Gournis, D. Graphene-based nafion nanocomposite membranes: Enhanced proton transport and water retention by novel organo-functionalized graphene oxide nanosheets. Small 2012, 8, 3338-3349. [CrossRef] [PubMed]

32. Patila, M.; Pavlidis, I.V.; Diamanti, E.K.; Katapodis, P.; Gournis, D.; Stamatis, H. Enhancement of cytochrome c catalytic behaviour by affecting the heme environment using functionalized carbon-based nanomaterials. Process Biochem. 2013, 48, 1010-1017. [CrossRef]

33. Pavlidis, I.V.; Tsoufis, T.; Enotiadis, A.; Gournis, D.; Stamatis, H. Functionalized multi-wall carbon nanotubes for lipase immobilization. Adv. Eng. Mater. 2010, 12, B179-B183. [CrossRef]

34. Pavlidis, I.V.; Vorhaben, T.; Tsoufis, T.; Rudolf, P.; Bornscheuer, U.T.; Gournis, D.; Stamatis, H. Development of effective nanobiocatalytic systems through the immobilization of hydrolases on functionalized carbon-based nanomaterials. Bioresour. Technol. 2012, 115, 164-171. [CrossRef] [PubMed]

35. Smith, P.K.; Krohn, R.I.; Hermanson, G.T.; Mallia, A.K.; Gartner, F.H.; Provenzano, M.D.; Fujimoto, E.K.; Goeke, N.M.; Olson, B.J.; Klenk, D.C. Measurement of protein using bicinchoninic acid. Anal. Biochem. 1985, 150, 76-85. [CrossRef]

36. Wolfenden, B.S.; Willson, R.L. Radical cations as reference chromogens in kinetic studies of one-electron transfer reactions: Pulse radiolysis studies of ABTS. J. Chem. Soc. Perkin Trans. 1982, 2, 805-812. [CrossRef]

37. Vazquez-Duhalt, R.; Westlake, D.W.S.; Fedorak, M.P. Kinetics of chemically modified lignin peroxidase and enzymatic oxidation of aromatic nitrogen-containing compounds. Appl. Microbiol. Biotechnol. 1995, 42, 675-681. [CrossRef]

38. Spyrou, K.; Calvaresi, M.; Diamanti, E.K.; Tsoufis, T.; Gournis, D.; Rudolf, P.; Zerbetto, F. Graphite oxide and aromatic amines: Size matters. Adv. Funct. Mater. 2015, 25, 263-269. [CrossRef]

39. Spyrou, K; Potsi, G.; Diamanti, E.K.; Ke, X.; Serestatidou, E.; Verginadis, I.I.; Velalopoulou, A.P.; Evangelou, A.M.; Deligiannakis, Y.; van Tendeloo, G.; et al. Towards novel multifunctional pillared nanostructures: Effective intercalation of adamantylamine in graphene oxide and smectite clays. Adv. Funct. Mater. 2014, 24, 5841-5850.

40. Kudin, K.N.; Ozbas, B.; Schniepp, H.C.; Prud'homme, R.K.; Aksay, I.A.; Car, R. Raman spectra of graphite oxide and functionalized graphene sheets. Nano Lett. 2008, 8, 36-41. [CrossRef] [PubMed]

41. Casiraghi, C.; Hartschuh, A.; Qian, H.; Piscanec, S.; Georgi, C.; Fasoli, A.; Novoselov, K.S.; Basko, D.M.; Ferrari, A.C. Raman spectroscopy of graphene edges. Nano Lett. 2009, 9, 1433-1441. [CrossRef] [PubMed]

42. Zhang, Y.; Zhang, J.; Huang, X.; Zhou, X.; Wu, H.; Guo, S. Assembly of graphene oxide-enzyme conjugates through hydrophobic interaction. Small 2012, 8, 154-159. [CrossRef] [PubMed]

43. Wei, X.L.; Ge, Z.Q. Effect of graphene oxide on conformation and activity of catalase. Carbon 2013, 60, 401-409. [CrossRef]

44. Cao, L. Covalent Enzyme Immobilization. In Carrier-Bound Immobilized Enzymes; Wiley-VCH Verlag GmbH \& Co. KGaA: Weinheim, Germany, 2006; pp. 169-316.

45. Iyer, P.V.; Ananthanarayan, L. Enzyme stability and stabilization-Aqueous and non-aqueous environment. Process Biochem. 2008, 43, 1019-1032. [CrossRef]

46. Patila, M.; Pavlidis, I.V.; Kouloumpis, A.; Dimos, K.; Spyrou, K.; Katapodis, P.; Gournis, D.; Stamatis, H. Graphene oxide derivatives with variable alkyl chain length and terminal functional groups as supports for stabilization of cytochrome c. Int. J. Biol. Macromol. 2016, 84, 227-235. [CrossRef] [PubMed]

47. Nair, R.R.; Demarche, P.; Agathos, S.N. Formulation and characterization of an immobilized laccase biocatalyst and its application to eliminate organic micropollutants in wastewater. New Biotechnol. 2013, 30, 814-823. [CrossRef] [PubMed]

48. Qiu, H.; Xu, C.; Huang, X.; Ding, Y.; Qu, Y.; Gao, P. Adsorption of laccase on the surface of nanoporous gold and the direct electron transfer between them. J. Phys. Chem. C 2008, 112, 14781-14785. [CrossRef]

49. Dodor, D.E.; Hwang, H.M.; Ekunwe, S.I.N. Oxidation of anthracene and benzo(a)pyrene by immobilization laccase from Trametes versicolor. Enzym. Microb. Technol. 2004, 35, 210-217. [CrossRef]

50. Majcherczyk, A; Johannes, C.; Hüttermann, A. Oxidation of polycyclic aromatic hydrocarbons (PAH) by laccase of Trametes versicolor. Enzym. Microb. Technol. 1998, 22, 335-341. 
51. Han, M.J.; Choi, H.T.; Song, H.G. Degradation of phenanthrene by Trametes versicolor and its laccase. J. Microbiol. 2004, 42, 94-98. [PubMed]

52. Hu, X.; Wang, P.; Hwang, H. Oxidation of anthracene by immobilized laccase from Trametes versicolor. Bioresour. Technol. 2009, 100, 4963-4968. [CrossRef] [PubMed]

53. Johannes, C.; Majcherczyk, A.; Hüttermann, A. Degradation of anthracene by laccase of Trametes versicolor in the presence of different mediator compounds. Appl. Microbiol. Biotechnol. 1996, 46, 313-317. [CrossRef] [PubMed]

54. Munteanu, F.D.; Cavaco-Paulo, A. Biosensors based on laccase for detection of commercially reactive dyes. Anal. Lett. 2010, 43, 1126-1131. [CrossRef]

55. Asgher, M.; Bhatti, H.N.; Ashraf, M.; Legge, R.L. Recent developments in biodegradation of industrial pollutants by white rot fungi and their enzyme system. Biodegradation 2008, 19, 771-783. [CrossRef] [PubMed]

56. Lanzafame, J.M.; Muenter, A.A.; Brumbaugh, D.V. The effect of J-aggregate size on photoinduced charge transfer processes for dye-sensitized silver halides. Chem. Phys. 1996, 210, 79-89. [CrossRef]

(C) 2016 by the authors; licensee MDPI, Basel, Switzerland. This article is an open access article distributed under the terms and conditions of the Creative Commons by Attribution (CC-BY) license (http://creativecommons.org/licenses/by/4.0/). 